\title{
Physico-Chemical Analysis of Ground Water Quality of Bhanvad
}

\author{
Tarun M. Patel ${ }^{1}$, Pramod K. Mahour ${ }^{2}$, Ranjeeta K. Mahour ${ }^{2}$, Hitendra K. Lautre ${ }^{3}$, \\ Purvesh J. Shah ${ }^{4, *}$ \\ ${ }^{1}$ Kadi Sarva Vishwavidhyalaya, Gandhinagar, India \\ ${ }^{2}$ Department of Chemistry, Shri Jagdish Prasad Tibrewala University, Jhunjhunu, India \\ ${ }^{3}$ Department of Chemistry, Columbia Institute of Engineering and Technology, Raipur, India \\ ${ }^{4}$ Department of Chemistry, K. K. Shah Jarodawala Maninagar Science College, Ahmedabad, India
}

\section{Email address:}

purvesh23184@gmail.com (P. J. Shah)

*Corresponding author

\section{To cite this article:}

Tarun M. Patel, Pramod K. Mahour, Ranjeeta K. Mahour, Hitendra K. Lautre, Purvesh J. Shah. Physico-Chemical Analysis of Ground Water Quality of Bhanvad. International Journal of Economy, Energy and Environment. Vol. 2, No. 5, 2017, pp. 87-89.

doi: $10.11648 /$ j.ijeee.20170205.12

Received: May 8, 2017; Accepted: August 22, 2017; Published: September 26, 2017

\begin{abstract}
Ground water samples were collected from diverse spaces of Bhanvad taluka of Jamnagar district (India) for investigation of their Physicochemical parameters. These Fifteen water samples from diverse spaces were analyzed for their physicochemical characteristics. Local community utilized this water for drinking and irrigation purpose. Laboratory investigations were carried out for analysis like, Temperature, Calcium-Magnesium hardness, pH, TDS, Chloride, Alkalinity, sulphate, phosphate and nitrate. These parameters are effectiveness in calculating quality of ground water. The key plan of our study is to find the quality of ground water in and around Bhanvad taluka and formulate it for drinking purposes after appropriate purification.
\end{abstract}

Keywords: Bhanvad Taluka, Physiochemical Parameters, Ground Water

\section{Introduction}

The wander of the natural world is Water. In nature water is one of most vital requirement for all the living organisms. Therefore it is true that "No water No life". For sustain of life under ground and surface water are essential natural resources, which is available in large quantity and it is a complimentary reward of nature [1-2]. In diverse forms and from diverse resources the water use for the human beings. Primarily two resources of drinking water, among them one is a surface water which includes River, lakes and second one is under ground water which are mainly from the escape of surface water and is detained in the subsoil and in prior rock. Ground water contains approximately $94 \%$ of total available water all over world. Major resource of drinking water in villages is under ground water which is available in the form of wells, bore wells or hand pumps [3-6].

As the population of world enlarge the require for cleans water also increases constantly. Public in numerous parts of the world are survival for lack of the fresh, drinkable water, therefore more protected water supplies are required.

Here we reported the physicochemical analysis of bore wells drinking water of Bhanvad territory. Bhanvad is situated in Jamnagar district of Gujarat. Bore wells water is usually utilize for Drinking and additional household functions in this area. The main sources of bore wells water pollution are the use of fertilizers and pesticides manure, lime, septic tank, refuse dump, etc. [7-9] For this reason, locality of this area required to utilize bore wells water for their drinking, domestic and other utilization. With the aim to evaluate water quality index, we have carried out the Physico-chemical analysis of bore wells drinking water.

\section{Material and Methods}

The Bore wells underground water samples of drinking water of Bhanvad taluka, were collected from 15 diverse 
villages in the morning between 10 am to 12 am in plastic sampling bottles with essential protections. For the preparation of reagents and solutions double distilled water was utilized. The main water quality parameters measured for the inspection in this study are temperature, $\mathrm{pH}$, dissolved oxygen (DO), total dissolved solid (T.D.S), total alkalinity, calcium and magnesium ions, sulphate, phosphate and nitrate contents [10]. Complexometric titration method was applied for estmination of Calcium and magnesium hardness of water $[9,11]$. Volumetrically Chloride and Sulphate contents were determined [11]. The Various Physico-chemical parameters of ground water samples of Bhanvad taluka are shown in the Table-1.

Table 1. Physico-chemical parameters of ground water samples.

\begin{tabular}{|c|c|c|c|c|c|c|c|c|c|c|c|}
\hline Sample Station & Temp ${ }^{\circ} \mathrm{C}$ & $\mathbf{p H}$ & TDS & $\begin{array}{l}\text { D.O. } \\
\mathrm{m} / \mathrm{L}\end{array}$ & $\mathrm{Cl}^{-} \mathrm{mg} / \mathrm{L}$ & $\begin{array}{l}\text { T.A. } \\
\text { mg/L }\end{array}$ & $\begin{array}{l}\text { C.H. } \\
\text { mg/L }\end{array}$ & $\begin{array}{l}\text { M.H. } \\
\text { mg/L }\end{array}$ & $\begin{array}{l}\mathrm{SO}_{4}{ }^{-2} \\
\mathrm{mg} / \mathrm{L}\end{array}$ & $\begin{array}{l}\mathrm{PO}_{4}^{-3} \\
\mathrm{mg} / \mathrm{L}\end{array}$ & $\begin{array}{l}\mathrm{NO}^{-3} \\
\mathrm{mg} / \mathrm{L}\end{array}$ \\
\hline Laiyara & 29.9 & 7.5 & 225 & 6.1 & 92.78 & 659 & 11.21 & 12.6 & 326.66 & 7.05 & 272 \\
\hline Jaiva & 29.5 & 7.2 & 845 & 7.9 & 115.78 & 592 & 13.53 & 29.46 & 75.04 & 9.55 & 362 \\
\hline Sagaliya & 31.2 & 8.2 & 465 & 7.5 & 98.92 & 396 & 14.27 & 27.59 & 40.79 & 4.05 & 222 \\
\hline Sudhadhuna & 30.9 & 7.6 & 405 & 7.2 & 84.15 & 351 & 33.14 & 64 & 278.56 & 5.55 & 117 \\
\hline Dharampur & 29.1 & 7.3 & 1005 & 6.3 & 145.65 & 666 & 23 & 31.16 & 168.1 & 6.55 & 132 \\
\hline Latipur & 28.6 & 6.9 & 745 & 8.2 & 27.68 & 613 & 10.92 & 81.28 & 124.5 & 7.35 & 82 \\
\hline Modpar & 29.9 & 8.1 & 705 & 7.5 & 78.95 & 503 & 15.72 & 95.52 & 171.1 & 10.55 & 137 \\
\hline Haripar & 31.2 & 7.3 & 495 & 7 & 43.48 & 658 & 36.64 & 20.59 & 251.84 & 8.55 & 247 \\
\hline Gokulpar & 33.8 & 8.2 & 675 & 5.8 & 127.1 & 471 & 43.48 & 16.66 & 238.6 & 4.55 & 317 \\
\hline Sanosara & 32.9 & 7.7 & 605 & 7.1 & 111.02 & 392 & 52.1 & 33.99 & 347.99 & 3.55 & 197 \\
\hline Sumra & 30.3 & 7.6 & 1430 & 6.5 & 86.28 & 620 & 10.29 & 42.09 & 347.5 & 6.55 & 92 \\
\hline Itala & 31.9 & 7.6 & 405 & 8.2 & 37.2 & 550 & 17.07 & 27.71 & 121.8 & 7.05 & 252 \\
\hline Rajpar & 28.4 & 7.9 & 565 & 6.7 & 119.82 & 642 & 7.97 & 30.02 & 86.74 & 15.05 & 114 \\
\hline Jabida & 27.5 & 7.1 & 205 & 7 & 75.74 & 342 & 28.61 & 17.14 & 161.51 & 10.05 & 147 \\
\hline Dedakdad & 29.5 & 7.5 & 835 & 8.4 & 53.94 & 488 & 33.24 & 79.44 & 56.65 & 7.05 & 138 \\
\hline Laiyara & 29.9 & 7.5 & 225 & 6.1 & 92.78 & 659 & 11.21 & 12.6 & 326.66 & 7.05 & 272 \\
\hline
\end{tabular}

$\mathrm{Cl}^{-:}$Chloride, T.A.: Total Alkalinity, C.H.: Ca Hardness, M.H.: Mg Hardness

\section{Results and Discussion}

Due to diverse nature of soil contamination the results of the bore wells water samples varies [12]. Water temperature are generally influenced the entire metabolic, physiological activities and life of aquatic organisms.

\section{Temperature}

Temperature range was situating between $27.5^{\circ} \mathrm{C}$ to $33.5^{\circ} \mathrm{C}$ for present analysis.

$p H$

The acidity, alkalinity and resulting value of the acidic basic interaction of a number of its mineral and organic components are depends on the $\mathrm{pH}$ value of drinking water. The corrosion in pipes starts when $\mathrm{pH}$ less than 6.5. Presences of Toxic metals in water increase the $\mathrm{pH}$. The acceptance $\mathrm{pH}$ limit is 6.5 to 8.5 . In the present study $\mathrm{pH}$ ranged from 7.1 to 8.2 which is suitable according to APHA1.

\section{TDS (Total Dissolved Substance)}

TDS value should be below than $500 \mathrm{mg} / \mathrm{L}$ for drinking water according to WHO and Indian standards [12, 13]. TDS ranged from $205 \mathrm{mg} / \mathrm{L}$ to $1430 \mathrm{mg} / \mathrm{L}$ are found in the present study.

\section{D.O. (Dissolved Oxygen)}

In the present analysis dissolved oxygen (D.O) found in between $5.8 \mathrm{mg} / \mathrm{L}$ to $8.4 \mathrm{mg} / \mathrm{L}$. and the minimum tolerance range is $4.0 \mathrm{mg} / \mathrm{L}$ for drinking water.

\section{Chlorides}

The tolerance range for chloride is 200 to $1000 \mathrm{mg} / \mathrm{L}$. In present study it found in between $37.2 \mathrm{mg} / \mathrm{L}$ to $145.65 \mathrm{mg} / \mathrm{L}$.

Total Alkalinity
We found total alkalinity range was from $342 \mathrm{mg} / \mathrm{L}$ to 666 $\mathrm{mg} / \mathrm{L}$.

Water hardness due to Calcium ion $\left(\mathrm{Ca}^{2+}\right)$

The calcium ion ranges from $7.97 \mathrm{mg} / \mathrm{L}$ to $52.1 \mathrm{mg} / \mathrm{L}$ with the tolerance range is 75 to $200 \mathrm{mg} / \mathrm{L}$. Water provides total requirements Calcium in the body.

Water hardness due to Magnesium ion $\left(\mathrm{Mg}^{2+}\right)$

Magnesium ion ranges from 12.60 to $95.52 \mathrm{mg} / \mathrm{L}$, their tolerance range is 50 to $100 \mathrm{mg} / \mathrm{L}$.

Sulphate ion $\left(\mathrm{SO}_{4}{ }^{2-}\right)$

Sulphate ion ranges from $40.79 \mathrm{mg} / \mathrm{L}$ to $347.99 \mathrm{mg} / \mathrm{Land}$ their tolerance range is 200 to $400 \mathrm{mg} / \mathrm{L}$. The diarrhea may induce due to high concentration of sulphate.

Phosphate ion $\left(\mathrm{PO}_{4}^{3-}\right)$

In the present study phosphate ranged from $3.55 \mathrm{mg} / \mathrm{L}$ to $15.05 \mathrm{mg} / \mathrm{L}$, which is much higher than the prescribed values. It may be due to exploit of fertilizers and pesticides by the people of this area. Excess phosphate consumption could lead to the death of consumer.

Nitrate ion $\left(\mathrm{NO}^{3-}\right)$

In the present study nitrate ranged from $82 \mathrm{mg} / \mathrm{L}$ to 362 $\mathrm{mg} / \mathrm{L}$ and their tolerance range for $20 \mathrm{mg} / \mathrm{L}$ to $45 \mathrm{mg} / \mathrm{L}$., which are higher than the prescribed values it may be due the excess use of fertilizers and pesticides.

\section{Conclusion}

In continuous of our previous work [14] in present research paper we describe the study of various Physicochemical analysis of bore wells water like, temperature, $\mathrm{pH}$, dissolved oxygen, total dissolved solids, chloride, total 
alkalinity, calcium and magnesium hardness, sulphate, phosphate nitrate ions. TDS value should be less than 500 $\mathrm{mg} / \mathrm{L}$ for drinking water. All the sample shows suitable ranged prescribed by WHO and Indian standards except than sample 11,which was found higher. It can affect living organisms.

\section{References}

[1] M. L. Chauhan, N. N. Vyas, R. N. Pandya, V. R. Patel, and N. Vohrab, "Physico-chemical studies on bore wells water of Godhra Taluka territory (Gujarat)". Archives of Applied Science Research, 4(1), 426-432, 2012.

[2] G. Madhurambal, and S. Ponsadai Lakshmi, "Ground Water Quality Assessment for Different purpose in Nagapattinam District, Tamilnadu, India.” An International Journal of Chemistry. 1(2), 108-119, 2010.

[3] G. D. Acharya, M. V. Hathi, Asha D. Patel, K. C. Paramar, "Chemical properties of Groundwater in Bhiloda Taluka Region, North Gujarat, India." E-journal of Chemistry, 5(4)792-796, 2008.

[4] M. V. Kadu, "Drinking Water Analysis of Buldana District, Maharashtra", Current World Environment, 6(2), 295-297, 2011.

[5] M. Alam, and J. K. Pathak, "Rapid Assessment of Water Quality Index of Ramganga River, Western Uttar Pradesh (India) ", Nature and Science; 8(11), 256-259, 2010.
[6] M. R. Mahananda, B. P. Mohanty, and N. R. Behera, "physico-chemical analysis of surface and ground water of bargarh district, orissa, india," IJRRAS, 2(3), 284-302, 2010.

[7] N. D. Sharma, J. N. Patel, "Evaluation of Groundwater Quality Index of the Urban Segments of Surat City, India." International journal of geology, 1(4), 220-245, 2010.

[8] S. Bhattacharjee, S. Chakravarty, S. Maity, V. Dureja, and K. K. Gupta, "Metal contents in the groundwater of Sahebgunj district, Jharkhand, India, with special reference to arsenic." Chemosphere, 58, 1203-1217, 2005.

[9] C. R. Ramakrishanaiah, C. Sadashivaiah, and G. Ranganna, "Assessment of water quality index for the ground water in Tumkur Taluk, Karnataka state, India, E. J. Chem. 6(2), 523530, 2009.

[10] N. G. Telkapalliwar and B. B. Shende, "Analysis of some physico-chemical parameters of ground water in Gondpipri Region Chandrapur District (Maharastra)." J. Chem. Pharm, 3(1), 176-179, 2011.

[11] N. R. Prasad and J. M. Patil, "A study of physico-chemical parameters of krishna river water particularly in western maharashtra," Rasayan J. Chem., 1(4), 943-958, 2008.

[12] WHO, Guidelines for drinking water quality Index, Geneva, 1984.

[13] WHO, International Standards for drinking water WHO, Geneva, 1994.

[14] T Patel, PK Mahour, R Mahour, HK Lautre and P Shah, "Physico-Chemical Analysis of Ground Water Quality of Dhrol", Environ Sci Ind J., 12(12), 127-133, 2016. 